\title{
Reforming the International Accounting Standards IAS/IFRS: A Need to Recover the Financial Stability? \\ Dr. Omar Djafri
}

\author{
PhD Management of Organizations, Member of LA.R.M.H.O laboratory \\ University of Abu Bekr BELKAÏD Tlemcen Algeria \\ Email : omardjafri@hotmail.fr \\ Mohammed Amine Taleb \\ PhD Student in Management of Organizations, Member of LA.R.M.H.O laboratory \\ University of Abu Bekr BELKAÏD Tlemcen Algeria \\ Email : amine.taleb13@yahoo.fr

\section{Dr. Abdelnacer Bouteldja} \\ Head of Department of Economics, Preparatory School of Economics, \\ Business and Management, Tlemcen, Algeria
}

Doi:10.5901/mjss.2014.v5n15p141

\begin{abstract}
We shall demonstrate in this paper, how often has the recent financial crisis been amplified by rising economic downturns. First, we will establish a brief description about the financial stability, then we'll see what will be the effects of fair value on the cycle of financial crisis and then finally, we'll see that beyond international accounting standards it's the measurement at fair value that should be reviewed.
\end{abstract}

Keywords: Accounting standards, financial stability, financial market and financial crisis.

\section{Introduction}

Financial stability has become nowadays a major source of concern globally, especially with the successive crises in Asia, Latin America and in the world.

The issue of the international financial system rests in one hand on the methods used to evaluate its strength and the other hand on the institutions to maintain its durability.

These institutions include the IASB (International Accounting Standards Board), which is a private organization whose mission is to develop standards that must adapt to changing financial markets, gold, since disruption of these markets in 2007; accounting standards are singled out, among the potential culprits of the crisis.

To this end, we will try in this work to answer the following question:

Is reform of accounting standards necessary to recover financial stability?

This question leads to a series of questions, including:

1. It means financial stability and its different pillars?

2. What is the implication of accounting standards in the financial crisis?

3. How does the fair value accelerate this financial crisis?

4. What was the reaction of regulators deal with this financial instability situation?

\section{Issues of Financial Stability}

Financial stability reflects a situation in which the functioning of the various components of the financial system and especially their mutual relations are guaranteed healthy and without major disruptions (BCEAO (2006)).

Therefore, financial stability is a result of the effectiveness of different mechanisms to protect the sustainability of the international financial system. 


\subsection{The importance of financial stability:}

The importance of financial stability is summarized in two (2) main points:

\subsubsection{Convergence towards the economic and social development:}

Through the role of the financial system, this provides mediation between economic agents and channels funding flows efficiently to the growth sectors.

\subsubsection{Maintaining trust between the different actors in credit institutions :}

This depends on the quality of institutional arrangements and payment systems in place that encourage risk-taking by credit institutions and investment decisions or investment by non-financial agents.

\subsection{The pillars of financial stability:}

Regulation of the financial system is based on three (3) pillars:

* The prudential regulation ;

* The internal control;

* Market discipline.

\subsubsection{Prudential regulations:}

Prudential regulation based on the requirements for sound and prudent conduct of banking and financial activities, compliance controls and instruments to take corrective action.

In this perspective, two (2) institutions are frequently discussed since the 70s: The Basel Committee and the IASB.

a) The Basel Committee:

The Basel Committee's main role is to deal with on a regular basis matters relating to banking supervision (prudential supervision).

Prudential supervision includes three functions: regulation, checking (supervision of enforcement) and supervision (observation of the behavior of actors) (Delphine Tordjman (2004)).

The main objective of the Basel Committee is to improve the stability of the international financial system by introducing capital requirements applicable to all banks.

$>$ The Basel I agreements

In 1988, the Basel Committee has set up the first Basel I, also called the Cooke ratio, which represents the minimum level of capital that must be held for the protection of depositors according to the bank credits to them granted ( liabilities).

In the Cooke ratio:

Regulatory capital / credit commitments sets $>8 \%$

The ratio of the two values must not be less than $8 \%$ according to Basel I.

The Basel I has been applied in more than one hundred countries, but despite this success, the Cooke ratio does not take into account the quality of the borrower ( credit risk that it represents ), the operational risks for banks (fraud staff and system failure ) and market risks.

$>$ The Basel II agreements

Basel II standards constitute a prudential framework for better understanding of the banking risks, mainly credit risk, using an internal credit rating for each establishment called IRB (Internal Ratings Based). In other words, the bank uses its internal ratings and estimates the probability of default for each borrower.

Under Basel II, a bank may also use a rating agency in the light of determining the appropriate level of capital.

Entered into force in 2008, the recommendations of Basel II have implemented the McDonough ratio to replace the Cooke ratio.

In the McDonough ratio:

Taken into account / equity (Credit Risk + Operational Risk + Market Risk) > 8\%

The transition from Basel I to Basel II has been progressed in many areas. Credit risk is well evaluated and treated better, and return to the subprime crisis, the risks associated with securitization procedures are better priced into account 
in Basel I (Report of the Economic Analysis Council (2008)).

Despite the improvements made by Basel II, by making consistent with equity risks by financial institutions, some economists believe that its recommendations have forced European banks to use more than ever estimates " credit risk " by rating agencies, including Moody's and Standard \& Poor's. These agencies have been much criticized for the temporal scope of their short analysis and their ratings do not fully measure the credit risk.

b) The International Accounting Standards Board ( IASB ):

The IASB focuses on developing a range of products applicable to companies called public offering (EPA) and banks for more transparency international standards.

\subsubsection{Internal control:}

Internal control appeared in the 1990s in connection with the growing sophistication of financial markets, the ambition is therefore to propose an alternative to regulation by transferring some control to financial actors themselves.

Self-regulation appears to Jezebel Couppey - Soubeyran ${ }^{\star 1}$ as a real key to the sustainability of the international financial system. Two (2) following reasons help to enhance internal control:

* Suggest a three-pillar strategy ( regulatory, internal control and market discipline) rather than one ;

* Empower actors directly involved in the regulation of the financial system (banks).

\subsubsection{Market discipline :}

Market discipline describes the overall transparency rules established by its stakeholders (shareholders, rating agencies, etc...) to make publicly available relevant information on the assets, risks and their management.

Among the players market discipline considered most relevant, we include (POP Adrian (2005)):

a) Shareholders:

In financial theory of the firm, shareholders are the first to suffer losses in case of bankruptcy. Thus, shareholders are a source of discipline can limit opportunistic behavior of some leaders and promote prudent governance.

b) Members of the Board of Directors (BoD):

The shareholders exercise control over the bank and officers elected by their representatives in the $\mathrm{BoD}$. The prestige associated with this delegation encourages board members to monitor the behavior of leaders and limit excessive risk taking.

c) Credit Rating Agencies:

Credit rating agencies play a very useful role in the exercise of market discipline by forcing banks to disclose certain information, generally unfavorable. In the absence of the rating process, the banks are in fact less likely to disclose this information.

Other actors are equally important:

$\checkmark$ Executives;

$\checkmark$ Carriers paper;

$\checkmark$ Subordinated creditors;

$\checkmark$ Great uninsured depositors.

\section{To the Path of International Accounting Standards}

All accounting standards are based on the concept of securing the objective of financial reporting. This goal can be different from a standard-setter to another to better meet the needs of investors (Barbe and Didelot (2011) ), the fact to provide an accurate picture of economic reality. In other words, the financial information in international standards is oriented primarily on the needs of capital providers.

It is important that accounting standards are revised and modified according to the changing economic environment and accounting practices of entities, giving primacy to economic reality over legal.

Steadily since 2005, when they were adopted in the European Union , IFRS (International Financial Reporting Standards) have emerged as the system, which in a few years will be the world's only be used by businesses.

\footnotetext{
* Jézabel Couppey-Soubeyran: Lecturer in Economics at the University of Paris 1.
} 


\subsection{IFRS, a real book revolution:}

The IASB has developed standards that can be the key to establish common rules for the dual purpose to standardize and streamline the presentation of accounting information that meet the needs of multiple users suspected object. The concept of accounting standards means all the rules to be applied by organizations, mainly companies in the preparation and presentation of financial statements and in their bookkeeping.

To improve the functioning of financial markets, listed companies are required to apply a single set of international accounting standards for the preparation of their consolidated financial statements.

From the presumed usefulness of financial statements for equity investors devoted to the reactions of the financial markets accounting information, it appears that financial statements play a decisive role in decision making. These studies are largely based on the assumption of market efficiency.

However, recent research has concluded that capital markets are inefficient with respect to at least three areas: the announcement of accounting unexpected results, the market value / book value of equity ratio and the key elements of the financial statements (Kothari (2001)).

It is difficult to measure quantitatively and academic manner the interests of comparability of accounting information for financial markets, however, this impact is a priori essential if accounting is a language, it is quite natural to think that the fact of having a common language between all actors should promote transparency of information ( Disle Charlotte Christine Christmas (2007)) .

To launch this revolution, it will have to break the power of the financial caste that controls all the political and economic workings ( Hoarau (2003) ) .

IAS / IFRS are threefold:

$>$ The content of financial statements, i.e. what we should recognize.

$>$ Valuation rules.

Disclosures to explain the accounts.

Their development is guided by theory, the accounting framework. Normalization by the principles focuses more on the spirit of the standard to the letter, and it requires the preparer of financial statements and the auditor to analyze the accountability issue in its economic and legal contexts.

The lack of resources allocated to a real professionalization of standardization in Europe, has left the field open to the accountants and auditors whose job is to promote the widest possible dissemination of a single international standard in a global market.

These standards appeal to a higher level of analysis and interpretation ability. Their use by preparers of financial statements requires, therefore, a long period of assimilation or the use of audit firms (Burlaud and Hoarau, 1999).

Table 1: Outline Of Changes In Accounting Standards

\begin{tabular}{|l|c|c|}
\hline & Consolidated accounts & Individual accounts \\
\hline Companies making public offerings (APE) & IAS / IFRS mandatory & System converging with IASB standards \\
\hline The consolidating unlisted companies & IAS / IFRS optional (recommended) & System converging with IASB standards \\
\hline Other (SME SMI) & IASB develops tailored IFRS for SMES & Simplified system converging with IASB standards \\
\hline
\end{tabular}

Source: Hoarau (2003) revisited by us

We may add that the mark-to-market challenge makes it the conventional accounting model more conscious of the duration and the time horizon of the Management Company and conventional accounting model generalizes a shareholder approach over the logic of the sustainable investment.

\subsection{Fair value as the generator of the financial relevance:}

The current economy is commonly described as the information economy (Disle Charlotte Christine Christmas (2007)); this information influences the economic decisions taken by the users on the basis of the financial statements. The relevance of financial information may be defined as its ability to estimate the true profitability of a company and its explanatory power of the market value of a company.

The financial information under IFRS must now respond to new questions such as: "What is the real value of the assets of the business?" Or "What is wealth creation for shareholders?" 
It is important to note that the principle of value to be based between knowledgeable parties acting at arm's length, so you do not have any responsibility for the financial crisis.

Henceforth, the fair value is defined as "the price at which an asset could be sold or transferred in a transaction entered into under normal conditions between market participants at the valuation date (exit price)" (IFRS 13).

It is used to revalue certain assets or liabilities at closing. However, she will improve readability, relevance, reliability and comparability of company accounts? This does not go without many problems, including:

$>$ IFRS refers to the quality of financial information to investors, or they are not the only users of this information.

$>$ Insufficient consensus born of the practice raises questions of interpretation.

$>$ Abundance of information may harm the interests of the company.

The concept of fair value underlies almost all IFRS accounting principles. She is very active in standards especially regarding financial instruments. Various IFRS requires the use of fair value or for certain items of the balance sheet, either for additional information. In the context of a diversity of information provided by the standards of fair value, IFRS 13 aims to create a single body of rules on the determination of fair value and to eliminate differences that might exist today. The publication of this IFRS is accompanied by changes in U.S. accounting rules, in order to make homogeneous the two standards on this point (Benoît Lebrun (2011)). The key issue of this method is rather the credibility of financial reporting risk, too: "too much information kills information" (Working Group "Fair value" (2007)).

There are four steps to determine fair value:

1. Define the asset or liability being measured.

2. Determine the optimal use of a financial asset.

3. Identify the market in which an orderly transaction would intervene.

4. Choose the most appropriate technique in the evaluation.

This fair value was introduced by the International Accounting Standards, is not new. She teaches accounting old debates of two centuries (Yuri Biondi et al (2008)). At present, it is a global issue.

We can say that the relevance and reliability of fair value are based on the existence of markets with high frequency trading, incorporating expectations of future correct. The goal is to obtain a better assessment of the business through a more transparent and comparable financial information. So what is the degree of achievement of the objectives established by the entities that could measure the consistency of the standards used?

One could say that the main positive fair value rely on the criticisms raised against the historical cost valuation, this valuation does not vary depending on the behavior and intentions of users of financial information but it ignores the concept of economic value, therefore, the fair value was found to be the most appropriate method, and to lead to a satisfactory assessment. In addition, technical progress in information, communication and dematerialization has accelerated the speed of transactions and international trade systems.

The principle of fair value represents, in the mind, a major change compared to historical cost.

The issue of fair value is the treatment of financial instruments inventory period. This process is based on the intention by the company during the implementation of the operation, either the asset or liability. To this end, it shall classify the instrument, according to its nature and its financial prospects of detention. This classification leads to record the transaction in one of four possible portfolios (see table below) and deduce the treatment to be applied in inventory.

Table 2: Classification Of A Financial Instrument By Nature

\begin{tabular}{|l|c|c|}
\hline \multicolumn{1}{|c|}{ Title } & Intention & Processing inventory \\
\hline Fair value based on earnings & $\begin{array}{c}\text { Short-term outcome } \\
\text { Only choice for derivatives }\end{array}$ & Valuation through profit results \\
\hline Available for Sale & Detention without particular horizon & Valuation against equity \\
\hline Loans and receivables & After the operation & Actuarial smoothing \\
\hline Détention & After the operation & Actuarial smoothing \\
\hline
\end{tabular}

Source: Stéphane Lefranq (2009).

In the end, it is appropriate to declare that the fair value will allow a better approximation of the economic reality of financial markets. 


\section{The Current Provision of IFRS Faces the International Financial System}

Researchers believe that accounting standards are deeply involved in the financial crisis and at the same time they believe that these crises have shaped the evolution of accounting standards (Marcus and Babes-Bolyai (2011)).

So we will start with the criticisms raised in relation to the fair value and of course propose solutions that will achieve greater financial stability. We also try to confirm or deny whether there will be other models for valuing financial instruments, other than "mark- to-market" 2

\subsection{Critical vis-a-vis the fair value :}

The IASB method is based on the assumption of efficient markets where the price of a financial security is supposed to perfectly reflect its characteristics (expected risk involved, liquidity, etc. Yield) and in a liquid market, the assets and liabilities are easily and quickly exchanged.

So, in an efficient market, investors are rational and well-informed, they evaluate the firm at its fair value, if there is a difference between the book value and the market value of the company, it is the market who is right (Dominique Plihon (2007)) .

Despite the advantage of fair value that reflects much better the financial assets of a company at a given time, the efficiency hypothesis is largely denied by reality (André Farber and Victor Ginsburgh (2010)). This leads us to ask the two following questions:

$\checkmark$ What is the impact of fair value when markets cease be liquid and become irrational?

$\checkmark$ How to measure financial instruments in times of crisis while the concept of fair value is based on the assumption of an efficient market?

Indeed, in this context of crisis, it is unclear how the valuation of financial assets may be realized optimally, on one hand, access to information is difficult and on the other hand, a real mistrust phenomenon is taking place between actors, quickly making illiquid ${ }^{3}$ securities markets become inactive. It becomes very difficult to make the fair value of securities for which there is no visibility.

Knowing that most of the banks' balance sheets is comprised of financial instruments, we understand why they continue to seek a rapid relaxation of fair value. Immediate exposure of banks to the volatility of financial markets has caused a destruction of value related to the impairment of assets (Gaudel and Deforge (2009)).

Critics have also risen against the "pro- cyclical"4 fair value effect. For this reason, in October 2008, the President of the French Republic "Nicolas Sarkozy", speaking on behalf of the Eurogroup, said that the IAS / IFRS standards had a responsibility in the global financial situation and the urgency to amend them. Also in the field of financial science, many experts believe that during the financial crisis period, the fair value is no longer the economic reality but the vagaries of the market.

Today, accounting standards remain at the center of debates that are based on the criticisms raised in relation to the valuation at fair value. This is an accounting principle that has undeniable implications in terms of financial volatility and amplification cycles. It has also allowed banks to register immediately increasing unrealized gains from their trading of financial instruments, and therefore, an increase in their capital sometimes called artificial.

This quickly resulted in:

$\checkmark$ The loss of investor confidence.

$\checkmark$ The soaring interbank rates.

High exposure of banks to market volatility and loss of investor confidence have questioned how the mechanisms of the international financial system and to drive financial instability.

Also, other criticisms have been leveled against the IFRS standard setter for governance: the IASB is integrated into a private foundation that belongs to a self-proclaimed no representative character group for this purpose; a minority

\footnotetext{
2 The mark-to-market is to assess regularly or permanently, a position based on its observed value on the market at the time of evaluation (Vernimmen definition).

${ }^{3}$ In a situation of illiquidity, the determination of fair value becomes critical because of the deteriorating global financial situation and this is explained by the phenomenon of mistrust that is taking place between the actors, which leads to a scarcity of transactions involving excessively low prices and resulting in abnormally low valuations and massive provisioning in the financial statements presentations actors. In this sense, the market becomes inactive and illiquid securities are returned promptly.

${ }^{4}$ The pro-cyclical nature of fair value is based on the enhancement of economic expansion and recession phases. I.e. when all goes well, the fair value increases the impression of value creation but when markets tighten, it accelerates the fall (Demaria (2009)).
} 
of individuals is fully satisfied by the current governance scheme, even after the introduction of "monitoring board "5.

\subsection{Feedback regulators:}

Faced with this situation of financial instability, and political authorities quickly realized the need to engage in a genuine reform process, it became important for regulators to provide an urgent response to issues related to procyclicality Accounting Standards .

\subsubsection{The first steps taken by the IASB :}

In 2008, the IASB amended IAS 39 and IFRS 7 aligning the methodology of classification of financial instruments on the U.S. GAAP, which helped to erase the major differences between IFRS and U.S. GAAP and to catch up on the competitive advantage of U.S. banks. The IASB has complemented these provisions by publishing an application guide October 31, 2008, giving a number of insights into the determination of fair value in inactive markets (IASB Expert Advisory Panel (2008)).

As part of these reforms two main components can be distinguished in the new approach to international accounting standards (Gaudel and Deforge (2009)):

1- The authorities allowed in the current context, the reclassification of assets measured at fair value normally in asset usually valued at amortized cost categories. These destination categories are: assets held to maturity, on one hand, and loans and receivables granted on the other.

* The decrease in the number of categories of financial instruments (deletion of the category of investments held to maturity, or elimination of the category of financial assets available for sale).

* The replacement of all the methods used by the principle of fair value, including the long-term operations (by now only a few exceptions).

* The simplification of hedge accounting (which could go up to his retirement, especially if the principle of fair value is used for all instruments).

2- The regulator also said that the preparer of financial information could have used a financial model based on the assumptions of management to determine the fair value of a financial asset if it is impossible to refer to relevant market values (substitution of mark- to-model to mark- to-market) . In contrast, the market price may be an adjustment models used by the entities element, the preparer must ensure to take into account all the parameters including liquidity risk, difficult to appreciate in times of crisis.

It will also be for the IASB to work with prudential supervisors in order to reduce the adverse effects during the crisis of the couple "IFRS - Basel II Accords"

We can therefore express and declare that if there is an active market, it is necessary to retain the price of financial instrument as fair value. If there is no active market, it is necessary to seek a valuation technique. This technique can take into account the price of financial instruments, it can also make use of valuation models (or other mathematical models discounted cash flows).

\subsubsection{Suggestions and recommendations of the G20 to the IASB :}

In 2009, the G20 published a report on strengthening the financial system that was part of his commitment for reforming this sector. This report included a series of reforms to be undertaken by regulators, rating agencies and standard-setters. He urged them to work to improve consistency in the standards for evaluation and to achieve a single set of global accounting standards of high quality.

In addition, the G20 leaders proposed to IASB to further strengthen cooperation with stakeholders and the support of its own advocacy.

These enhancements are implemented for anticipation of the needs arising from revision of the administration strategy and provide ongoing monitoring of the normative life cycle.

At the summit held in Cannes (France), on 3 and 4 November 2011, the G20 leaders made recommendations for standards developers that they must:

* Modernize provisions provisioning, exposure to off-balance sheet activities and uncertainties of recovery.

\footnotetext{
${ }_{5}^{5}$ Monitoring board est un conseil de surveillance doté d'un pouvoir de veto sur leurs futures nominations, et qui devait être l'instance supérieure de toute l'organisation de normalisation internationale.
} 
* Strengthen the provisions on accounting for impairment recognized on loans by adding information on the credit risk.

* Reduce the complexity of accounting rules on financial instruments.

* Improve standards on valuation of financial instruments based on the liquidity of these forecasts and detention investors, while reaffirming the framework of application of fair value accounting.

* Achieve significant progress towards a single set of accounting standards of high quality.

* Move the involvement of stakeholders, including prudential regulators and emerging economies.

The International Accounting Standards Board (IASB) published November 9, 2011, an updated version of the work done or to be done, he undertook the following actions:

* Finalization of the comprehensive review of off balance sheet financing ( Amendments to IFRS 7: Transfers of Financial Assets ( disclosures) ;

* Publication in May 2011 of a new body of standards on consolidation (IFRS 10, 11 and 12);

* Publication of IFRS 13 , which provides clearer and more consistent on the application of fair value in inactive markets methods ;

* Publication in November 2009 of a first exposure draft on impairment of financial instruments, taking into account an expected loss model and in January 2011 a supplement to this paper, in collaboration with the FASB :

* Completion in 2010 of the various phases of IFRS 9 :

$>$ Phase I: Recognition and measurement of assets and accounting for financial liabilities;

$>$ Phase II: Impairment ;

$>$ Phase III: Hedge Accounting.

* Publication in December 2010 of a first exposure draft on hedge accounting.

Other common work FASB / IASB are planned during 2012 to achieve global convergence of IFRS and U.S. GAAP.

\section{Conclusion}

This study aims to restore some financial stability which depends mainly on the health of financial markets. During the recent financial crisis, banks, hedge funds, rating agencies, regulators and can be added to the list the international accounting standards, are open to criticism, is responsible for the worsening of the crisis. We in our research, set sail on the international standard setter in this case the IASB, including the importance it attaches to the concept of fair value. This valuation method has been heavily criticized and is in the center of many debates between supporters and opponents of an Anglo- Saxon concept of accounting.

Our goal was to prove that the fair value is not the main cause of the financial crisis, and it is not a sufficient condition to achieve better measurement of financial assets in listed companies, it is malfunctioning in crisis period, but it is not enough to disqualify immediately. In this regard, a mixed model including the three valuation methods (fair value mark to model - amortized cost) is recommended.

The Basel Committee that promote and strengthen banking supervision practices and risk management objective, also has a major role to play in strengthening the financial system, through new reforms " Basel III ", whose the most important is the introduction of new liquidity ratios since January 2013, to allow banks to better withstand situations of financial instability.

\section{References}

Burlaud Alain et Hoarau Christian, « Accounting harmonization and globalisation », Actes de l'IFSAM, World Management Conference 1999, The Global Management Revolution, Keynote Speeches, Pékin, juillet 1999.

Pop Adrian, «La discipline de marché dans la régulation bancaire : le rôle de la dette subordonnée », Thèse de Doctorat en Sciences Économiques, Université d'Orléans, Décembre 2005, pp. 40-43.

Meder Anthony et al, « Structured Finance and Mark-to-Model Accounting: A Few Simple Illustrations », Accounting Horizons American Accounting Association, vol. 25, N³, 2011, pp. 559-576.

Banque Centrale des Etats de l'Afrique de l'Ouest (BCEAO), revue de la stabilité financière de l'UEMOA, 2006.

Lebrun Benoît, « La norme IFRS 13 sur l'évaluation à la juste valeur », Revue Française de Comptabilité, Juin 2011 n444, pp. 3-4.

Hoarau Christian, « Place et rôle de la normalisation comptable en France », Revue française de gestion, 2003/6 n 147, pp. 33-47.

Cristina M. Marcus, Babes-Bolyai, « Are crises one of the rationales used by International Accounting Standards Board to gain global dominance ? », European Journal of Management, volume 11, n4 2011, pp.128-132. 
Tordjman Delphine, « Risque de système et dispositif prudentiel de la zone euro », journée d'étude sur les crises financières, Orléans, 6 7 mai 2004, p 10.

Disle Charlotte et Noël Christine, « La révolution des normes IFRS, Une convergence de la comptabilité vers la finance?», La Revue des Sciences de Gestion, 2007/2 n²24-225, p17-27.

Plihon Dominique, «les nouvelles normes comptables internationales: une réforme aux implications considérables », L'Économie politique, 2007, page79.

Farber André et Ginsburgh Victor, «Crise financière et normes comptables », Reflets et perspectives de la vie économique, 2010/1 Tome XLIX, pp. 23-30.

Groupe de travail "Fair value", Comité Jacques Coeur, « Juste valeur La recherche de la pertinence ? », Échanges d'expériences DFCG Île-de-France, Janvier 2007 n² 239, pp 56-58.

Decornoy Jean-Luc, « De la nécessité de l'évolution des normes comptables », in Jean-Louis Chambon, Repenser la planète finance, regards croisés sur la crise financière, Edition d'Organisation, les Echos Editions, Paris 2009, pp. 237-250.

Raimondo Lo Russo, « Où en est-on avec le projet de l'IASB de norme IFRS adaptée pour les PME ? », La Revue des Sciences de Gestion, 2010/5 n² 245-246, pp. 141-148.

Rapport du Conseil d'Analyse Économique, La crise des Subprimes, Paris, 2008, page 129.

Revue Fiduciaire Comptable, N³85, Juillet-Août 2011, pp. 16-17.

Gaudel Pierre-Jean et Deforge Jérôme, «IFRS: Les normes comptables sont-elles un accélérateur de crise ? », JCP/La semaine juridique-Éditions entreprises et affaires $N^{\circ}$ 23, 4 juin 2009, Page 44.

Demaria Samira, «La comptabilité a-t-elle un rôle dans la crise financière ?, Présupposés et réalités », Avocats-Publishing, Paris 18 mars 2009.

Lefranq Stéphane, « Juste valeur ou valeur injuste : Le débat sur l'évaluation des instruments de marché », Revue française de la comptabilité, $n^{\circ} 418$, février 2009.

Kothari S. P., « Capital markets research in accounting », Journal of Accounting and Economics, 31, September 2001, pp. 105-231.

Biondi Yuri et al, « La juste valeur, enfin une évaluation proche de la réalité », in Anne Pezet et Samuel Sponem, Petit bréviaire des idées reçues en management, sous la direction, Edition la découverte, Paris 2008, pp. 210-218. 